\title{
Effect of Substitution with Mango Peels and Seed Kernels as By-Products on the Quality of Pan Bread and Cake \\ Faten Y. Ibrahim $^{1}$; E. A. Aboulnaga ${ }^{1}$; M. R. G. Youssif ${ }^{2}$ and M. A. El-Gaafary ${ }^{1}$ \\ ${ }^{1}$ Food Science Department, Faculty of Agriculture, Mansoura University, Mansoura, Egypt \\ ${ }^{2}$ Bread and Pasta Research Department, Food Technology Research Institute, Agricultural Research Center, Giza, Egypt
}

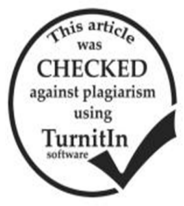

ABSTRACT

Mango peels and seeds are the major by-products of mango juice industry. They are rich in natural bioactive compounds such as dietary fibers, vitamins, minerals, and antioxidants compounds, which play an important role in human nutrition. In the present study, mango peels powder (MPP) and mango seed kernels powder (MSKP) were used to prepare pan bread and cake with replacing levels $(2.5,5.0,7.5$ and $10 \%)$ from the wheat flour ( $72 \%$ extraction). The effect of these replacing levels on rheological properties of dough as well as physical, staling, and sensory characters of pan bread and cake was evaluated. Chemical composition of MPP revealed that it had higher contents of ash, crude fibers, dietary fibers, and minerals $(\mathrm{K}, \mathrm{Na}, \mathrm{Ca}$, $\mathrm{Mg}$, and $\mathrm{Zn}$ ), while MSKP characterized by higher fat, protein, dietary fiber, and minerals ( $\mathrm{K}, \mathrm{Ca}, \mathrm{Mn}$, and $\mathrm{Zn})$ contents. On the rheological level, increasing the substitution ratio of both MPP and MSKP from 0 up to $10 \%$ increased dough water absorption and degree of softening. Meanwhile, dough stability, resistance to extension, and dough energy were gradually decreased. In addition, these substitutions caused gradually increased in weight values, while volume and specific volume of bread and cake were gradually decreased by increasing substitution level. Additionally, substitution with MPP and MSKP retarded the rate of the products staling. Furthermore, there was non significant difference in sensory characters between control samples, pan bread samples with substitution levels up to $5.0 \%$ of MPP and 7.5\% of MSKP, as well as cake with replacement level of 2.5 and $7.5 \%$, respectively. In conclusion, it could enhance pan bread and cake without change their physical, staling, and sensory properties with $2.5 \%$ of MPP or with MSKP up to $5.0 \%$ to take advantage of the active compound found in both.

Keywords: Pan bread- Cake- Mango peels- Mango seed kernels- Rheological properties- bakery products quality.

\section{INTRODUCTION}

Bakery products are the main sources for carbohydrates in the human's meals. Among these products bread which is an important staple food and consumed worldwide (Fan et al., 2007). White bread is more popular than high-fiber bread because of its organoleptic properties, however, there are increasing demands toward consumption of high-fiber breads due to their health prompting properties (Stanley and Linda, 2006). High-fiber bread is one of the known products categorized in 'Functional food' which is health beneficial due to its high contents of dietary fiber. According to what is reported by Galisteo et al. (2008), high dietary fiber intake has been proved to be beneficial for human health with reducing effect on colonic cancer.

Dietary fiber consists of a variety of non-starch polysaccharides which include cellulose, hemicellulose, pectin, $\beta$-glucans, gums and lignin (Lamghari et al., 2000).

Cell walls of fruits, vegetables, pulses, and cereals are the most sources of the dietary fiber intake (Jimenez, et al., 2000). Dietary fibers from cereals are more frequently used than those from vegetables and fruits. The benefits to use vegetables and fruits as sources for dietary fibers are: firstly, their dietary fiber more better quality than cereals due to higher total and soluble fiber content, higher water and oil holding capacity, higher colonic fermentability, lower phytic acid content, and lower caloric value (Larrauri et al., 1997). Secondly, fruits and vegetables contain a significant amount of bioactive compounds such as antioxidants, mainly phenolic compounds, flavonoids, phenolic acids (Leontowicz et al., 2002) linked to the fiber matrix that makes a significant contribution to the health benefits attributed to the dietary fiber. They are many fruits for example orange, apple, peach, and mango that are used for juice extraction. All of them contain a by-product from which can be recovered different high-added value compounds such as dietary fibers that has a great potential in the preparation of functional foods (Sharoba et al., 2013).

Mango (Mangifera indica L.), which belongs to the family Anacardiaceae, is one of the most cultivated fruit in the world. Because mango is a seasonal fruit, about $20 \%$ of fruits are processed for products such as juice, nectar, pulp, puree, fruit leather, pickles, and canned slices (Larrauri et al., 1996). These processes produced several million tons of mango-wastes annually. There are several varieties grown in Egypt, the better known cultivars are alphonso, pairi, zebda, mabroka, balady and succary (El-Soukkary et al., 2000). The world production of mango fruits more than 43 million tons while, Egypt is among the top 10 mango producing countries (FAO, 2012).

Mango peels are considered to be a by-product from industrial processing or consumption of the fruit. The peel composes approximately $7-24 \%$ of the mango fruit total weight (Kim et al., 2012). Recently, mango peels have attracted considerable attention in the scientific community due to their high content of valuable compounds such as phytochemicals, polyphenols, carotenoids, enzymes, vitamin E, and vitamin $\mathrm{C}$, which have predominant functional and antioxidant properties (Ajila et al., 2007). These valuable compounds are also beneficial for human health. Mango peels can be utilized for the production of valuable ingredients (i.e., dietary fibers and polyphenols) for various food applications, as has been reported by many researchers (Aziz et al., 2012). Currently, mango peel powder is used as a functional ingredient in many food products such as noodles, bread, sponge cakes, biscuits, and other bakery products (Aziz et al., 2012).

Like mango peels, mango seeds are also discarded as by-products during industrial processing of the fruit. Depending on the varieties, the kernel represents $45-85 \%$ of the seed and approximately $20 \%$ of the whole fruit (Solís-Fuentes and Durán-de-Bazúa, 2011). On a dry 
basis, the seed kernel contains $7.1-15 \%$ crude fats depending on the varieties (Jahurul et al., 2013 and 2014). This fat has attracted considerable interest due to its unique physical and chemical characteristics, which are similar to those of cocoa butter, illipe, shea, kokum, and sal butter (Muchiri et al., 2012 \& Jahurul et al., 2013). So, it is a promising safe and natural source of edible fats, as it does not contain any trans-fatty acids (Solís-Fuentes and Duránde-Bazúa, 2011).

Nowadays consumers prefer to eat healthy foods in order to prevent non-communicable diseases. For this reason industry and researchers are involved in optimizing bakery products making technology to improve the variety, quality, taste, and availability (Hathorn et al., 2008). So, the aim of the present study was designed to evaluate the effect of mango by-products (MPP and MSKP) on rheological properties of pan bread and cake as well as physical, chemical, and sensory characteristics.

\section{MATERIALS AND METHODS}

\section{Materials:}

Wheat flour (72\% extraction, Five Stars Flour Mills Company, Suez, Egypt), instant active dry yeast, sucrose, salt, corn oil, eggs, shortening, dry milk, baking powder, and vanilla were obtained from local market, El-mansoura city, Egypt.

Mango peels and mango seed kernels (cultivars zebda and succary) were obtained from Misr-Italy Company for concentrates and food industries-New Damietta, Damietta, Egypt.

\section{Methods:}

Analytical methods:

Proximate chemical composition of raw materials (moisture, ash, lipids, crude fibers, total dietary fibers, and nitrogen contents) was determined according to A.O.A.C (2016). Soluble and insoluble dietary fibers were determined according to method described by Prosky et al. (1988). Total carbohydrate was calculated by differences.

Some minerals such as $\mathrm{K}, \mathrm{Na}, \mathrm{Ca}, \mathrm{Mg}, \mathrm{Fe}, \mathrm{Zn}$, and $\mathrm{Mn}$ were determined by atomic absorption spectrophotometry after it was wet acid digested according to Chapman and Pratt (1978) method.

Rheological Characteristic:

Farinograph test:

Farinograph parameters were measured using Farinograph (Brabender Duis Bur G, type 810105001 No. 941026 made in West Germany) according to A.A.C.C. (2010).

\section{Extensograph test:}

Extensograph parameters were measured according to A. A. C. C. (2010) method using Extensograph (Brabender Duis Bur G type 860001 No. 946003 made in West Germany).

Preparation of mango peels and mango seed kernels powders:

Mango peels were separated from the waste and promptly collected. Then, the peels were washed with water and dried in air circulation oven at $60^{\circ} \mathrm{C}$ for 8 hours.

Mango seeds were washed and dried in air oven and kernels were manually removed by dehiscing the hard coat. The seed kernels were chopped and air dried at $50^{\circ} \mathrm{C}$ for overnight. The dried peels and seed kernels were milled to a fine powder and sieved on 110 mesh sieve.

\section{Preparation of flour blends:}

Different flour blends were prepared by partially substituting of wheat flour by $2.5,5.0,7.5$, and $10 \%$ of MPP or MSKP. These blends were used in preparation of experimental samples of pan bread and cakes.

\section{Preparation of pan bread:}

Pan bread was prepared from wheat flour $(72 \%)$ only as a control and from flour blends prepared above according to A.A.C.C., 2010 method with small modification described in Aboulnaga et al. (2018).

Preparation of cakes:

Cake was prepared according to (Bennion et al., 1997). The cake batter was formulated from $100 \mathrm{~g}$ flour or flour blends, $85 \mathrm{~g}$ whole fresh eggs, $85 \mathrm{~g}$ sucrose, $55 \mathrm{~g}$ shortening, $3 \mathrm{~g}$ dry milk, $3.8 \mathrm{~g}$ baking powder and $0.6 \mathrm{~g}$ vanilla.

Physical properties of bakery products:

The weight of bread loaves and cake were determined after cooling for one hour. Volumes were measured by rape seed displacement method as described by A. A. C.C. (2010). Specific volumes were calculated by dividing the volume $\left(\mathrm{cm}^{3}\right)$ by their weights $(\mathrm{g})$.

\section{Determination of bakery products staling:}

The staling rates of pan bread and cake samples were determined by alkaline water retention capacity method described by Kitterman and Rubanthaler (1971).

Sensory evaluation of bakery products:

Pan bread and cake were left to cool at room temperature for an hour after baking, then were cut with a sharp knife and subjected to ten panelists from the Food Science Dept., Faculty of Agric., Mansoura University. Pan bread loaves were organoleptically evaluated according to Gelinas and Lachance (1995), while cake was evaluated according to A.A.C.C. (2010) methods.

\section{Statistical analysis:}

ANOVA were analyzed using the producer of the Statistical Analysis System (SAS, 2010) software program.

\section{RESULTS AND DISCUSSION}

\section{Proximate chemical composition of raw materials:}

Proximate chemical composition of wheat flour, MPP and MSKP is presented in table (1). The obtained results revealed that the highest value of crude protein was recorded for wheat flour ( $72 \%$ ext.) being $12.61 \%$ followed by MSKP (6.28\%). On the other hand, MSKP presented higher lipids content than MPP. Meanwhile, MPP had the highest ash and crude fibers content followed by MSKP. These results are in agreement with Ravani and Joshi (2013) and Joyce et al. (2014).

Concerning the dietary fiber content presented in the same table, MPP and MSKP contains the highest percentage of total, soluble, and insoluble dietary fibers which amounted in 62.50, 19.32, and $43.18(\mathrm{~g} / 100 \mathrm{~g}$ dry crude fiber) for MPP and 24.98, 6.32, and 18.66 (g/ $100 \mathrm{~g}$ dry crude fiber) for MSKP, respectively. Alternatively, wheat flour $(72 \%$ ext.) showed the lowest content of dietary fibers. These results are in accordance with those obtained by Ajila et al. (2010) and Ravani and Joshi (2013). 
Also, from the results presented in the above mentioned table, it could be noticed that MPP and MSKP contains high amount of $\mathrm{K}$, Ca compared with wheat flour. They recorded 270.61 and $280.71 \mathrm{mg} / 100 \mathrm{~g}$ for $\mathrm{K}$ as well as 135.22 and $115.40 \mathrm{mg} / 100 \mathrm{~g}$ for $\mathrm{Ca}$, respectively. Meanwhile, MPP and MSKP have higher contents of micro-elements (Mn and $\mathrm{Zn}$ ) than wheat, which in MPP were 1.44 and $2.40 \mathrm{mg} / 100 \mathrm{~g}$, while in MSKP were 2.03 and $1.35 \mathrm{mg} / 100 \mathrm{~g}$, respectively. These results are in accordance with those obtained by Joyce et al. (2014).

Table 1. Proximate chemical composition of raw materials:

\begin{tabular}{lccc}
\hline & $\begin{array}{c}\text { Wheat flour } \\
\text { (72\% extraction) }\end{array}$ & MPP & MSKP \\
\hline \multicolumn{4}{c}{ Chemical composition (\%) } \\
Moisture & 12.38 & 8.44 & 10.22 \\
Crude protein & 12.61 & 2.47 & 6.28 \\
Lipids & 1.00 & 6.39 & 13.42 \\
Ash & 0.61 & 2.92 & 1.57 \\
Crude fiber & 0.91 & 11.40 & 2.47 \\
Total carbohydrate & 84.87 & 76.82 & 76.26 \\
\hline \multicolumn{4}{c}{ Dietary fiber (g/100g dry crude fiber) } \\
Total dietary fiber (TDF) & 4.53 & 62.50 & 24.98 \\
Soluble dietary fiber (SDF) & 2.14 & 19.32 & 6.32 \\
Insoluble dietary fiber (IDF) & 2.39 & 43.18 & 18.66 \\
\hline \multicolumn{4}{c}{ Minerals content (mg/100g dry basis) } \\
Potassium (K) & 153.65 & 270.61 & 280.71 \\
Sodium (Na) & 42.15 & 156.34 & 60.32 \\
Calcium (Ca) & 11.15 & 135.22 & 115.40 \\
Magnesium (Mg) & 35.02 & 28.73 & 10.32 \\
Manganese (Mn) & 1.12 & 1.44 & 2.03 \\
Iron (Fe) & 0.95 & 1.13 & 1.27 \\
Zinc (Zn) & 0.45 & 2.40 & 1.35 \\
\hline
\end{tabular}

Farinograph parameters:

Table (2) presented farinograph parameters of wheat flour and flour blends with MPP or MSKP. The water absorption of wheat flour was gradually increased as the level of substitution with MPP or MSKP increased which reached to $64.8 \%$ and $62.5 \%$ for substitution level of $10 \%$, respectively in compared to $60.4 \%$ for the control dough. This increment in water absorption probably due to the higher fiber contents of MPP and MSKP than wheat flour (Table, 1) as reported by Abd El-Moniem and Yaseen (1993), they said the addition of fiber sources to wheat flour caused an increased in water absorption of the produced dough.

Table 2. Farinograph parameters:

\begin{tabular}{|c|c|c|c|c|c|c|}
\hline Blends & & $\begin{array}{l}\text { *Water } \\
\text { absorption } \\
\text { (\%) }\end{array}$ & $\begin{array}{l}\text { ArrivalI } \\
\text { time } \\
\text { (min) }\end{array}$ & $\begin{array}{l}\text { evelopme } \\
\text { time } \\
\text { (min) }\end{array}$ & $\begin{array}{l}\text { t Dough } \\
\text { stability } \\
\text { (min) }\end{array}$ & $\begin{array}{c}\text { Degree of } \\
\text { softening } \\
\text { (BU) }\end{array}$ \\
\hline Control sa & ample & 60.4 & 2.0 & 4.0 & 8.0 & 90 \\
\hline \multirow{4}{*}{ MPP } & 2.5 & 61.2 & 2.0 & 4.0 & 7.0 & 100 \\
\hline & 5.0 & 62.6 & 2.5 & 4.0 & 6.0 & 110 \\
\hline & 7.5 & 63.7 & 3.0 & 4.5 & 5.0 & 140 \\
\hline & 10.0 & 64.8 & 3.5 & 4.5 & 3.0 & 160 \\
\hline \multirow{4}{*}{ MSKP } & 2.5 & 60.8 & 2.0 & 4.0 & 7.5 & 100 \\
\hline & 5.0 & 61.4 & 2.0 & 4.0 & 6.5 & 110 \\
\hline & 7.5 & 61.9 & 2.5 & 4.5 & 6.0 & 120 \\
\hline & 10.0 & 62.5 & 2.5 & 4.5 & 5.5 & 120 \\
\hline
\end{tabular}

* Expressed on 14\% moisture basis. $\quad$ BU $=$ Brabender unit.
Also, it could be noticed that the arrival time and dough development time were taken the same trend like water absorption which increased with increasing the replacement levels with MPP and MSKP.

Dough stability time were decreased from $8.0 \mathrm{~min}$ for control to 7.0, 6.0, 5.0, and $3.0 \mathrm{~min}$ as well as to 7.5, $6.5,6.0$, and $5.5 \mathrm{~min}$ for wheat flour substituted with 2.5 , $5.0,7.5$, and $10 \%$ of MPP and MSKP, respectively. This decrement in the stability time indicates weakness of dough strength that reflects decrement in wheat gluten content (dilution effect) of the blends. These results agree well with those reported by Ajila et al. (2008).

Concerning the degree of softening, it could be noticed that the samples which recorded low dough stability, had higher softening values. So, the degree of softening values was gradually increased with increasing replacement levels of MPP and MSKP. These results are in good accordance with those reported by Ashoush and Gadallah (2011).

\section{Extensograph parameters:}

It could be noticed that extensograph parameters are affected by the replacement level as well as the type of addition. These parameters values were highly changed by the substitution with MPP than MSKP. As it seems from table (3), the maximum resistance to extension was highly decreased by increasing the replacement level of MPP rather than MSKP. This may be due to the dilution of wheat gluten as a result to addition of MPP and MSKP. The same trend was also observed for energy values as well as extensibility (Table, 3 ). These results are in agreement with those obtained by Ashoush and Gadallah (2011).

On the other hand, proportional number was slightly decreased with increasing the replacement level of MPP. In contrast, replacement with MSKP in general increased the proportional number than control in spite of it decreased by increasing the replacement level of MSKP.

Table 3. Extensograph parameters:

\begin{tabular}{|c|c|c|c|c|c|}
\hline Blends & & $\begin{array}{l}\text { Maximum } \\
\text { resistance to } \\
\text { extension } \\
\text { "R" (BU) }\end{array}$ & $\begin{array}{c}\text { Extensibility } \\
\text { "E" } \\
(\mathbf{m m})\end{array}$ & $\begin{array}{l}\text { Proportional } \\
\text { number } \\
(\mathrm{R} / \mathrm{E})\end{array}$ & $\begin{array}{l}\text { Energy } \\
\text { (Cm2) }\end{array}$ \\
\hline Control & nple & 800 & 175 & 4.57 & 185 \\
\hline \multirow{4}{*}{ MPP } & 2.5 & 700 & 170 & 4.12 & 152 \\
\hline & 5.0 & 620 & 155 & 4.00 & 132 \\
\hline & 7.5 & 450 & 115 & 3.91 & 68 \\
\hline & 10.0 & 350 & 90 & 3.89 & 47 \\
\hline \multirow{4}{*}{ MSKP } & 2.5 & 780 & 120 & 6.50 & 176 \\
\hline & 5.0 & 740 & 122 & 6.07 & 147 \\
\hline & 7.5 & 710 & 125 & 5.68 & 132 \\
\hline & 10.0 & 670 & 128 & 5.23 & 105 \\
\hline
\end{tabular}

* $\mathbf{B U}=$ Brabender unit. $\mathbf{m m}=$ Millimeter.

$\mathrm{R} / \mathrm{E}=$ resistance/ Extensibility.

\section{Physical measurements of pan bread:}

From the results presented in table (4), partial replacement of wheat flour with 2.5, 5.0, 7.5 and $10 \%$ of MPP or MSKP increased the weight of bread loaves gradually in parallel with increasing the level of substitution. The increasing in bread weight may be due to the increase in bread fiber contents which characterized by 
having higher water holding capacity as mentioned by Sudhakar and Maini (2000) \& Chaplin (2003).

On the other side, this replacement caused gradually decreased in bread volume and specific volume by increasing substitution level in compared to control sample. The high reduction in loaves volume that obtained with MPP rather than MSKP may be due to the low content of protein as well as the high content of fiber (Table, 1). These results are in agreement with that obtained by El-Soukkary et al. (2000) whom mentioned that bread loaf volume was gradually decreased with increasing the fiber content.

Table 4. Physical measurements of pan bread:

\begin{tabular}{|c|c|c|c|c|c|c|c|}
\hline \multirow{3}{*}{\multicolumn{2}{|c|}{$\begin{array}{l}\text { Bread } \\
\text { samples }\end{array}$}} & \multicolumn{6}{|c|}{ Physical measurement } \\
\hline & & \multicolumn{2}{|c|}{$\begin{array}{c}\text { Loaf } \\
\text { weight }\end{array}$} & \multicolumn{2}{|c|}{$\begin{array}{c}\text { Loaf } \\
\text { volume }\end{array}$} & \multicolumn{2}{|c|}{$\begin{array}{l}\text { Specific } \\
\text { volume }\end{array}$} \\
\hline & & (g) & $\%$ & $\left(\mathrm{~cm}^{3}\right)$ & $\%$ & $\left(\mathrm{~cm}^{3} / \mathrm{g}\right)$ & $\%$ \\
\hline Control s & mple & 255 & 100 & 1080 & 100 & 4.24 & 100 \\
\hline \multirow{4}{*}{ MPP } & $2.5 \%$ & 269 & 105 & 1020 & 94 & 3.79 & 89 \\
\hline & $5.0 \%$ & 285 & 112 & 993 & 92 & 3.48 & 82 \\
\hline & $7.5 \%$ & 305 & 120 & 915 & 85 & 3.00 & 71 \\
\hline & $10.0 \%$ & 330 & 129 & 850 & 79 & 2.57 & 61 \\
\hline \multirow{4}{*}{ MSKP } & $2.5 \%$ & 251 & 98 & 1055 & 98 & 4.20 & 99 \\
\hline & $5.0 \%$ & 263 & 103 & 1049 & 97 & 3.98 & 94 \\
\hline & $7.5 \%$ & 280 & 110 & 1033 & 96 & 3.68 & 87 \\
\hline & $10.0 \%$ & 289 & 113 & 1020 & 94 & 3.52 & 83 \\
\hline
\end{tabular}

Physical measurements of cake:

Results in table (5) show the effect of wheat

flour replacement on the physical measurements of cakes. The values recorded a similar trend as that observed for pan bread (Table, 4). When MSKP was used for substitution, the weight was gradually increased by increasing the substitution level until it was reached 16\% higher than control (Table, 5), while specific volume was gradually decreased and showed $24 \%$ less specific volume than control with $10 \%$ MSKP substitution. In contrast, cake volume has slight decrease than control. When MPP was used for replacement, it had less increment in weight than pan bread (Table, 4 ), which was $13 \%$ for cake and $29 \%$ for pan bread in the case of $10 \%$ MPP substitution. Also, less decrement in specific volume between cake and pan bread was also obtained (Table 4, 5). On the other hand, volume of cake and pan bread had almost similar decrement ratio. This only viable change in weight and specific volume with MPP may be due to the high water holding capacity of fiber under the pan bread processing condition than cake.

Staling rate of pan bread:

The staling rate of pan bread produced by using $100 \%$ wheat flour $(72 \%$ ext.) as control or substituted with 2.5, 5.0, 7.5 and 10\% of MPP and MSKP stored for 72 hours at room temperature $\left(25^{\circ} \mathrm{C}\right)$ are presented in figure (1). It is obvious that, there was a gradual decrease in freshness for all different pan bread samples during storage periods. These results are in agreement with that previously obtained by He and Hoseney (1990).

The partial replacement of wheat flour with 2.5, $5.0,7.5$ and $10 \%$ of MPP or MSKP slightly increased the values of alkaline water retention capacity for bread samples in parallel with increasing the level of substitution.
The lower reduction in staling value (high freshness) was noticed in pan bread sample which prepared by partial replacement of wheat flour with $10 \%$ of MPP or all the MSKP levels. These means that replacement of wheat flour by $2.5,5.0,7.5$ and 10\% MSKP caused a considerable improvement in bread freshness in compared to control sample. These observation may be due to the gradually increment of moisture content for pan bread which makes it more tenderness, improved in bread freshness and caused higher alkaline water retention capacity values. An enhancement of initial softness and decrement of bread firmness by increasing the absorption of water during baking were observed by Stauffer (2000) and Hug-Iten et al. (2003).

Table 5. Physical measurements of cakes:

\begin{tabular}{|c|c|c|c|c|c|c|c|}
\hline \multirow{3}{*}{\multicolumn{2}{|c|}{$\begin{array}{l}\text { Cake } \\
\text { samples }\end{array}$}} & \multicolumn{6}{|c|}{ Physical measurement } \\
\hline & & \multicolumn{2}{|c|}{ Weight } & \multicolumn{2}{|c|}{ Volume } & \multicolumn{2}{|c|}{$\begin{array}{l}\text { Specific } \\
\text { volume }\end{array}$} \\
\hline & & (g) & $\%$ & $\left(\mathrm{~cm}^{3}\right)$ & $\%$ & $\left(\mathrm{~cm}^{3} / \mathrm{g}\right)$ & $\%$ \\
\hline Control & imple & 679 & 100 & 1170 & 100 & 1.72 & 100 \\
\hline \multirow{4}{*}{ MPP } & $2.5 \%$ & 690 & 102 & 1133 & 97 & 1.64 & 95 \\
\hline & $5.0 \%$ & 713 & 105 & 1070 & 91 & 1.50 & 87 \\
\hline & $7.5 \%$ & 725 & 107 & 1030 & 88 & 1.42 & 83 \\
\hline & $10.0 \%$ & 769 & 113 & 920 & 79 & 1.19 & 69 \\
\hline \multirow{4}{*}{ MSKP } & $2.5 \%$ & 689 & 101 & 1150 & 98 & 1.66 & 97 \\
\hline & $5.0 \%$ & 701 & 103 & 1143 & 98 & 1.63 & 95 \\
\hline & $7.5 \%$ & 713 & 105 & 1110 & 95 & 1.55 & 90 \\
\hline & $10.0 \%$ & 790 & 116 & 1099 & 94 & 1.48 & 86 \\
\hline
\end{tabular}

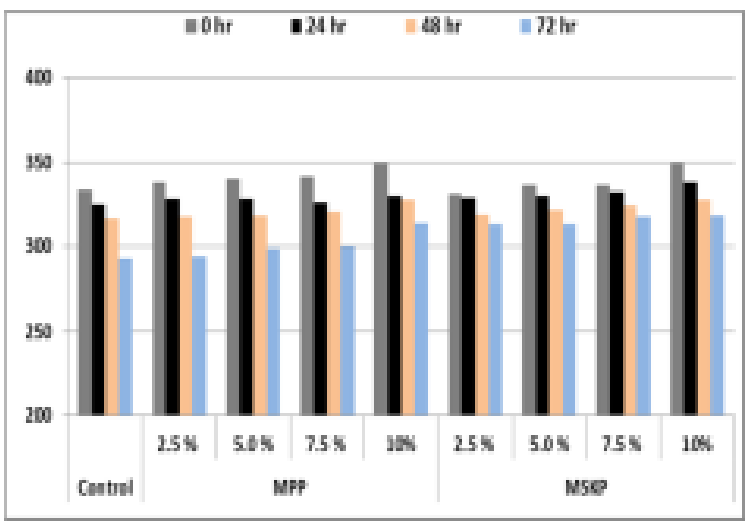

Figure 1. Staling rate of pan bread

\section{Staling rate of cake:}

The results of cake staling are illustrated in figure (2). The data showed that, there is gradual increased in freshness at zero time by increasing MPP levels, while this increment is observed only with 7.5 and 10\% MSKP. After week storage, cake samples that prepared by partial replacement of flour with 5.0, 7.5, and $10 \%$ of MPP or with all MSKP levels retained high freshness than others. While after two weeks, only substitution with $10 \%$ MPP had the highest freshness properties. However after three weeks, a high deterioration in cake freshness was observed for all cake samples. The increased in moisture content of cake samples makes it more tenderness, improved in cakes freshness and caused higher alkaline water retention capacity values as it is reported before by Maleki et al. (1980). 


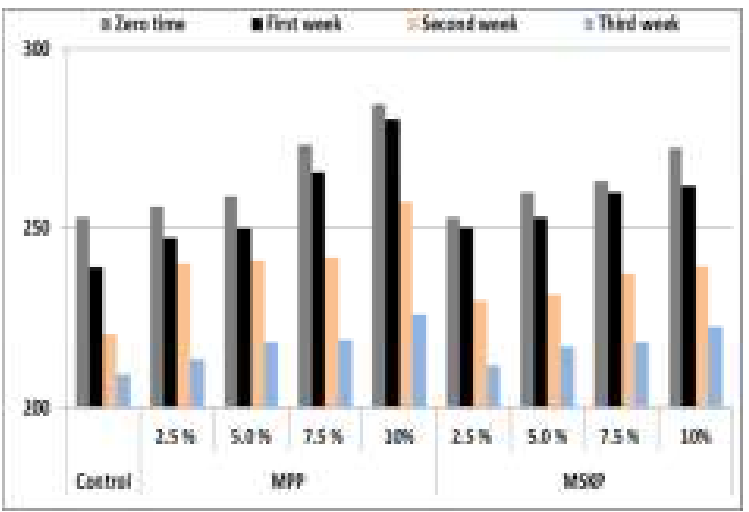

Figure 2. Staling rate of cake

Sensory evaluation of fresh pan bread:

Table (6) shows the organoleptic properties of pan bread produced by different blends with MPP or MSKP. From this result it could be observed that, there were no significant differences in crust color, crumb color, texture, taste, flavor, general appearance, and over all acceptability for the produced pan bread between the control sample and the substitution level of $2.5 \% \mathrm{MPP}$ and $5.0 \%$ MSKP. However, substitution with $7.5 \%$ MSKP significantly reduced only flavor and general appearance of pan bread than control. On the other hand, significant differences in all parameters were observed with replacement level of 7.5 and $10 \%$ MPP or $10 \%$ MSKP. These results are in agreement with those obtained by El-Soukkary et al. (2000) and Ajila et al. (2008).

Sensory evaluation of fresh cake:

Concerning organoleptic properties of cakes (Table, 7), cake samples prepared by partial replacement of wheat flour by $2.5,5.0$, and $7.5 \%$ of MSKP or $2.5 \%$ of MPP had no significant differences in all sensory parameters under investigation. Also, substitution with 5.0\% MPP could produce a cake with similar cell thickness, grain, texture, crumb color, and flavor properties as control. On the other hand, substitution with 10\% MPP or MSKP significantly reduced all the organoleptic properties of cake than control.

Table 6. Sensory characteristics of pan bread containing different levels of MPP and MSKP

\begin{tabular}{ccccccccc}
\hline Treatment & $\begin{array}{c}\text { Crust } \\
\text { Color (10) }\end{array}$ & $\begin{array}{c}\text { Crumb } \\
\text { Color (10) }\end{array}$ & $\begin{array}{c}\text { Texture } \\
(\mathbf{2 0 )}\end{array}$ & $\begin{array}{c}\text { Taste } \\
\text { (20) }\end{array}$ & $\begin{array}{c}\text { Flavor } \\
\text { (20) }\end{array}$ & $\begin{array}{c}\text { General } \\
\text { appearance (20) }\end{array}$ & $\begin{array}{c}\text { Over all } \\
\text { acceptability (100) }\end{array}$ \\
\hline Control & & $9.00 \pm 0.66^{\mathrm{A}}$ & $9.10 \pm 0.88^{\mathrm{A}}$ & $18.80 \pm 2.53^{\mathrm{A}}$ & $18.70 \pm 0.95^{\mathrm{A}}$ & $18.70 \pm 1.25^{\mathrm{A}}$ & $18.80 \pm 1.23^{\mathrm{A}}$ & $93.10 \pm 4.10^{\mathrm{A}}$ \\
\hline \multirow{4}{*}{$\mathrm{MPP}$} & 2.5 & $8.70 \pm 1.25^{\mathrm{A}}$ & $8.30 \pm 1.34^{\mathrm{AB}}$ & $18.40 \pm 1.17^{\mathrm{A}}$ & $18.50 \pm 2.72^{\mathrm{A}}$ & $18.00 \pm 4.16^{\mathrm{AB}}$ & $18.70 \pm 2.26^{\mathrm{A}}$ & $90.60 \pm 11.43^{\mathrm{AB}}$ \\
& 5.0 & $8.20 \pm 1.15^{\mathrm{AB}}$ & $8.00 \pm 1.05^{\mathrm{AB}}$ & $17.70 \pm 1.34^{\mathrm{AB}}$ & $17.80 \pm 2.66^{\mathrm{AB}}$ & $17.40 \pm 3.27^{\mathrm{AB}}$ & $17.70 \pm 2.21^{\mathrm{AB}}$ & $86.80 \pm 10.22^{\mathrm{AB}}$ \\
& 7.5 & $7.10 \pm 1.10^{\mathrm{B}}$ & $7.50 \pm 2.59^{\mathrm{B}}$ & $16.70 \pm 1.63^{\mathrm{B}}$ & $16.20 \pm 2.74^{\mathrm{B}}$ & $16.70 \pm 3.37^{\mathrm{B}}$ & $16.10 \pm 1.74^{\mathrm{B}}$ & $80.30 \pm 12.66^{\mathrm{B}}$ \\
& 10.0 & $7.00 \pm 1.61^{\mathrm{B}}$ & $6.10 \pm 0.88^{\mathrm{C}}$ & $14.60 \pm 1.84^{\mathrm{C}}$ & $14.70 \pm 2.16^{\mathrm{C}}$ & $15.40 \pm 2.41^{\mathrm{C}}$ & $16.00 \pm 2.54^{\mathrm{B}}$ & $73.80 \pm 7.95^{\mathrm{B}}$ \\
\hline \multirow{3}{*}{$\mathrm{MSKP}$} & 2.5 & $8.90 \pm 0.88^{\mathrm{AB}}$ & $8.70 \pm 0.95^{\mathrm{AB}}$ & $18.50 \pm 1.76^{\mathrm{A}}$ & $18.00 \pm 1.49^{\mathrm{AB}}$ & $17.10 \pm 1.66^{\mathrm{AB}}$ & $17.50 \pm 1.51^{\mathrm{AB}}$ & $88.70 \pm 10.12^{\mathrm{AB}}$ \\
& 5.0 & $8.20 \pm 0.79^{\mathrm{AB}}$ & $8.60 \pm 1.78^{\mathrm{AB}}$ & $17.40 \pm 2.11^{\mathrm{AB}}$ & $17.90 \pm 1.97^{\mathrm{AB}}$ & $16.90 \pm 1.73^{\mathrm{AB}}$ & $17.40 \pm 1.89^{\mathrm{AB}}$ & $86.40 \pm 5.80^{\mathrm{AB}}$ \\
& 7.5 & $8.00 \pm 1.41^{\mathrm{AB}}$ & $8.30 \pm 0.82^{\mathrm{AB}}$ & $17.20 \pm 1.14^{\mathrm{AB}}$ & $17.10 \pm 1.19^{\mathrm{AB}}$ & $16.20 \pm 2.20^{\mathrm{B}}$ & $16.70 \pm 1.49^{\mathrm{B}}$ & $83.50 \pm 6.91^{\mathrm{AB}}$ \\
& 10.0 & $7.10 \pm 0.87^{\mathrm{B}}$ & $7.00 \pm 1.49^{\mathrm{B}}$ & $16.50 \pm 1.43^{\mathrm{B}}$ & $16.20 \pm 1.55^{\mathrm{B}}$ & $16.10 \pm 0.99^{\mathrm{B}}$ & $16.20 \pm 1.81^{\mathrm{B}}$ & $79.10 \pm 6.15^{\mathrm{B}}$ \\
\hline
\end{tabular}

* Means followed by different letters in the same column are significantly different by $\mathrm{SAS}(\mathrm{p}<0.05)$.

Table 7. Sensory characteristics of cakes containing different levels of MPP and MSKP

\begin{tabular}{|c|c|c|c|c|c|c|c|c|c|c|c|}
\hline \multirow{2}{*}{\multicolumn{2}{|c|}{ Treatment }} & \multicolumn{3}{|c|}{ Cells (30) } & \multirow[b]{2}{*}{$\begin{array}{l}\text { Grain } \\
\text { (20) }\end{array}$} & \multicolumn{3}{|c|}{ Texture (30) } & \multirow{2}{*}{$\begin{array}{c}\text { Crumb } \\
\text { color } \\
(10)\end{array}$} & \multirow[b]{2}{*}{$\begin{array}{c}\text { Flavor } \\
\text { (10) }\end{array}$} & \multirow{2}{*}{$\begin{array}{c}\text { Over all } \\
\text { acceptability } \\
\text { (100) }\end{array}$} \\
\hline & & $\begin{array}{c}\text { Uniformity } \\
\text { (10) }\end{array}$ & $\begin{array}{l}\text { Size } \\
\text { (10) }\end{array}$ & $\begin{array}{c}\text { Thickness } \\
\text { (10) }\end{array}$ & & $\begin{array}{c}\text { Moistness } \\
\text { (10) }\end{array}$ & $\begin{array}{l}\text { Tenderness } \\
\text { (10) }\end{array}$ & $\begin{array}{l}\text { Softness } \\
\text { (10) }\end{array}$ & & & \\
\hline Control & & $9.0 \pm 1.05^{\mathrm{A}}$ & $8.5 \pm 2.37^{\mathrm{A}}$ & $8.0 \pm 1.41^{\mathrm{A}}$ & $18.2 \pm 2.89^{\mathrm{A}}$ & $8.5 \pm 1.35^{\mathrm{A}}$ & $8.6 \pm 1.65^{\mathrm{A}}$ & $8.8 \pm 1.14^{\mathrm{A}}$ & $8.9 \pm 0.88^{\mathrm{A}}$ & $8.7 \pm 1.25^{\mathrm{A}}$ & $87.2 \pm 9.17^{\mathrm{A}}$ \\
\hline \multirow{4}{*}{ MPP } & 2.5 & $8.5 \pm 1.51^{\mathrm{AB}}$ & $8.0 \pm 2.58^{\mathrm{AB}}$ & $7.4 \pm 2.37^{\mathrm{AB}}$ & $17.5 \pm 1.72^{\mathrm{AB}}$ & $7.7 \pm 1.34^{\mathrm{AB}}$ & $8.2 \pm 1.88^{\mathrm{A}}$ & $8.3 \pm 1.70^{\mathrm{AB}}$ & $8.6 \pm 0.84^{\mathrm{AB}}$ & $8.2 \pm 0.92^{\mathrm{AB}}$ & $82.4 \pm 6.00^{\mathrm{AB}}$ \\
\hline & 5.0 & $7.3 \pm 1.25^{\mathrm{B}}$ & $7.4 \pm 2.01^{\mathrm{B}}$ & $7.3 \pm 0.95^{\mathrm{AB}}$ & $17.2 \pm 2.25^{\mathrm{AB}}$ & $7.5 \pm 2.09^{\mathrm{AB}}$ & $7.3 \pm 1.16^{\mathrm{AB}}$ & $7.7 \pm 1.25^{\mathrm{AB}}$ & $7.6 \pm 1.65^{\mathrm{AB}}$ & $7.9 \pm 0.74^{\mathrm{AB}}$ & $77.2 \pm 13.79^{\mathrm{B}}$ \\
\hline & 7.5 & $7.2 \pm 1.62^{\mathrm{B}}$ & $6.5 \pm 2.55^{\mathrm{C}}$ & $6.4 \pm 2.27^{\mathrm{AB}}$ & $16.7 \pm 1.25^{\mathrm{B}}$ & $7.1 \pm 1.79^{\mathrm{B}}$ & $7.2 \pm 1.48^{\mathrm{AB}}$ & $7.5 \pm 1.72^{\mathrm{B}}$ & $6.9 \pm 1.59^{\mathrm{B}}$ & $7.5 \pm 1.27^{\mathrm{B}}$ & $73.0 \pm 9.73^{\mathrm{B}}$ \\
\hline & 10.0 & $6.8 \pm 1.69^{\mathrm{C}}$ & $6.1 \pm 1.85^{\mathrm{C}}$ & $6.2 \pm 1.55^{\mathrm{B}}$ & $16.2 \pm 2.62^{\mathrm{B}}$ & $6.6 \pm 1.71^{\mathrm{C}}$ & $6.9 \pm 1.91^{\mathrm{B}}$ & $7.2 \pm 1.93^{\mathrm{B}}$ & $6.6 \pm 1.96^{\mathrm{B}}$ & $7.1 \pm 1.52^{\mathrm{B}}$ & $69.7 \pm 12.99^{\mathrm{C}}$ \\
\hline \multirow{4}{*}{ MSKP } & 2.5 & $8.1 \pm 1.29^{\mathrm{AB}}$ & $7.8 \pm 1.83^{\mathrm{AB}}$ & $7.5 \pm 0.85^{\mathrm{AB}}$ & $17.4 \pm 1.58^{\mathrm{A}}$ & $8.2 \pm 1.23^{\mathrm{AB}}$ & $8.7 \pm 1.25^{\mathrm{A}}$ & $8.3 \pm 1.49^{\mathrm{AB}}$ & $7.5 \pm 2.92^{\mathrm{AB}}$ & $8.1 \pm 0.88^{\mathrm{AB}}$ & $81.6 \pm 5.90^{\mathrm{A}}$ \\
\hline & 5.0 & $7.9 \pm 1.08^{\mathrm{AB}}$ & $7.5 \pm 2.37^{\mathrm{AB}}$ & $7.4 \pm 1.58^{\mathrm{AB}}$ & $16.6 \pm 1.35^{\mathrm{AB}}$ & $7.9 \pm 1.29^{\mathrm{AB}}$ & $8.6 \pm 0.97^{\mathrm{AB}}$ & $8.1 \pm 1.19^{\mathrm{AB}}$ & $7.4 \pm 1.07^{\mathrm{AB}}$ & $7.9 \pm 0.99^{\mathrm{AB}}$ & $79.3 \pm 8.89^{\mathrm{AB}}$ \\
\hline & 7.5 & $7.6 \pm 1.58^{\mathrm{AB}}$ & $7.1 \pm 2.13^{\mathrm{AB}}$ & $6.7 \pm 1.49^{\mathrm{AB}}$ & $16.1 \pm 3.63^{\mathrm{AB}}$ & $7.8 \pm 1.03^{\mathrm{AB}}$ & $8.3 \pm 1.25^{\mathrm{AB}}$ & $7.7 \pm 0.95^{\mathrm{AB}}$ & $7.3 \pm 1.16^{\mathrm{AB}}$ & $7.8 \pm 1.03^{\mathrm{AB}}$ & $76.4 \pm 7.28^{\mathrm{AB}}$ \\
\hline & 10.0 & $7.3 \pm 1.34^{\mathrm{B}}$ & $6.0 \pm 1.49^{\mathrm{B}}$ & $6.4 \pm 2.01^{\mathrm{B}}$ & $14.8 \pm 4.51^{\mathrm{B}}$ & $7.4 \pm 1.71^{\mathrm{B}}$ & $7.1 \pm 1.85^{\mathrm{B}}$ & $7.2 \pm 1.75^{\mathrm{B}}$ & $6.7 \pm 1.34^{\mathrm{B}}$ & $7.5 \pm 1.18^{\mathrm{B}}$ & $70.4 \pm 7.28^{\mathrm{B}}$ \\
\hline
\end{tabular}

* Means followed by different letters in the same column are significantly different by $\operatorname{SAS}(\mathrm{p}<0.05)$.

\section{CONCLUSION}

Based on the above results, it could be concluded that mango peels powder and mango seed kernels powder could be used, as a potential source for bioactive components, in pan bread and cake making. The substitution level up to 2.5 of MPP and $5.0 \%$ of MSKP from the wheat flour could be produced pan bread and cake with good physical, staling, and sensory properties.

\section{REFERENCES}

A.A.C.C. (2010). American Association of Cereal Chemists. Approved Methods of the A.A.C.C. Published by the American Association of Cereal Chemists, $10^{\text {th }}$ Ed., St. Paul, MN. USA.

A.O.A.C. (2016). Official Methods of Analysis, $17^{\text {th }}$ Ed., Association of Official Analytical Chemists International. Gaithersburg, Maryland, USA. 
Abd El-Moniem, G.M. and A.A. Yaseen (1993). High dietary fiber cookies from several sources of bran or husk. Egypt J. Food Sci., 21 (2): 157-170.

Aboulnaga, E.A; F.Y. Ibrahim; M.R.G. Youssif and A.M.I. Mohamed (2018). Influence of various hydrocolloids addition on pan bread quality. J. of Food and Dairy Sciences, Mansoura Uni., Vol.(9), Issue No.(10), 2018

Ajila, C. M.; Naidu, K. A.; Bhat, S. G. and Prasada Rao, U. J. S. (2007). Bioactive compounds and antioxidant potential of mango peel extract. Food Chemistry, 105: 982-988.

Ajila, C.M.; Leelavathi, K. and Prasada Rao, U.J.S. (2008). Improvement of dietary fiber content and antioxidant properties in soft dough biscuit with the incorporation of mango peel powder. J. Cereal Sci., 48: 319-326.

Ajila, C.M.; Aalami, M.; Leelavathi, K. and Prasada Rao, U.J.S. (2010). Mango peel powder: A potential source of antioxidant and dietary fiber in macaroni preparations. Innovative Food Science and Emerging Technologies, 11:219-224.

Ashoush, I.S. and Gadallah, M.G.E. (2011). Utilization of Mango Peels and Seed Kernels Powders as Sources of Phytochemicals in Biscuit. World Journal of Dairy \& Food Sciences 6 (1): 35-42.

Aziz, N. A. A.; Wong, L. M.; Bhat, R. and Cheng, L. H. (2012). Evaluation of processed green and ripe mango peel and pulp flours (Mangifera indica var Chokanan) in term of chemical composition, antioxidant compounds and functional properties. Journal of the Science of Food \& Agriculture, 92: 557-563.

Bennion, E. B., Bamford, G. S. T., and Bent, A. J. (1997). Cake-making processes. In The technology of cake making (pp. 251-274). Springer, Boston, MA.

Chaplin, M.F. (2003). Fiber and water binding, Proceedings of the Nutrition Society, 62: 223-227.

Chapman, H.D. and Pratt, P.F. (1978). Methods of analysis for soils, plants and waters, Univ. California, Div. Agric. Sci., Priced publication 4034.

El-Soukkary, F.A.H.; EL-Sahn, M.A. and Mohamed, H.M.A. (2000). Physico-chemical and nutritional evaluation of mango seed kernel and its utilization for pan bread supplementation. Zagazig J. Agric. and Res., 27: 1319-1342.

Fan, L., Zhang, S., Yu, L., \& Ma, L. (2007). Evaluation of antioxidant property and quality of breads containing Auricularia auricula polysaccharide flour. Food chemistry, 101(3), 1158-1163.

FAO (2012). Annual production of mango fruits in Egypt, at the web page: http://www.fao.org/faostat/.

Galisteo, M.; Duarte, J. and Zarzuelo, A. (2008). Effects of dietary fibers on disturbances clustered in the metabolic syndrome. Journal of Nutritional Biochemistry 19: 71-75.

Gelinas, P. and Lachance, O. (1995). Development of fermented dairy ingredients as flavor enhancers for bread. Cereal Chem., 72 (1): 17-21.

He, H. and Hoseney, R.C. (1990). Changes in bread firmness and moisture during long-term storage. Cereal Chem., 67 (6): 603-605.
Hug-Iten, S.; Escher, F. and Conde-Pettit, B. (2003). Staling of bread: Role of amylase and amylopectin and influence of starch-degrading enzymes. Cereal Chem., 80 (6): 654-661.

Hathorn, C. S., Biswas, M. A., Gichuhi, P. N., \& BovellBenjamin, A. C. (2008). Comparison of chemical, physical, micro-structural, and microbial properties of breads supplemented with sweetpotato flour and high-gluten dough enhancers. LWT-Food Science and Technology, 41(5), 803-815.

Jahurul, M. H. A.; Norulaini, N. A. N.; Zaidul, I. S. M.; Jinap, S.; Sahena, F.; Azmir, J.; Sharif, K. M. and Mohd Omar, A. K. (2013). Cocoa butter fats and possibilities of substitution in food products concerning cocoa varieties, alternative sources, extraction methods, composition, and characteristics. Journal of Food Engineering, 117(4): 467-476.

Jahurul, M. H. A.; Zaidul, I. S. M.; Norulaini, N. N. A.; Sahena, F.; Jaffri, J. M. and Mohd Omar, A. K. (2014). Supercritical carbon dioxide extraction and studies of mango seed kernel for cocoa butter analogy fats. CyTA-Journal of Food, 12(1): 97103.

Jimenez, A.; Rodriguez, R.; Fernandez-Caro, I.; Guillen, R.; Fernandez-Bolanos, J. and Heredia, A. (2000). Dietary fiber content of table olives processed under different European styles: Study of physicochemical characteristics. Journal of the Science of Food and Agriculture, 80: 1903-1908.

Joyce, O.O; Latayo, B.L and Onyinye, A.C. (2014). Chemical composition and phytochemical properties of mango (mangifera indica.) seed kernel International Journal of Advanced Chemistry, 2 (2): 185-187.

Kim, H.; Kim, H.; Mosaddik, A.; Gyawali, R.; Ahn, K. S. and Cho, S. K. (2012). Induction of apoptosis by ethanolic extract of mango peel and comparative analysis of the chemical constitutes of mango peel and flesh. Food Chemistry, 133: 416-422.

Kitterman, S. and Rubanthaler, G.L. (1971). Assessing the quality of orally generation wheat selection with the micro AWRC test. Cereal Sci., Today, 16: 313.

Lamghari, R.; Sanchez, C.; El Boustani, E.; Maucourt, N. M.; Sauvaire, Y.; Mejean, L. and Villaume, C. (2000). Comparison of effects of prickly pear (Opuntia ficus indica sp.) fruits, arabic gum and citrus pectin on viscosity and in vitro digestibility of casein. Journal of the Science of Food and Agriculture, 80: 359-364.

Leontowicz, H., Gorinstein, S., Lojek, A., Leontowicz, M., Č́ž, M., Soliva-Fortuny, R., ... \& Martin-Belloso, O. (2002). Comparative content of some bioactive compounds in apples, peaches and pears and their influence on lipids and antioxidant capacity in rats. The Journal of nutritional biochemistry, 13(10), 603-610.

Larrauri, J. A.; Ruperez, P.; Borroto, B. and Saura-Calixto, F. (1996). Mango peels as a new tropical fiber: Preparation and characterisation. LWT - Food Science \& Technology, 29: 729-733. 
Larrauri, J. A., Rupérez, P., \& Saura-Calixto, F. (1997). Effect of drying temperature on the stability of polyphenols and antioxidant activity of red grape pomace peels. Journal of agricultural and food chemistry, 45(4), 1390-1393.

Maleki, M.; Hoseney, R.C. and Mattern, P.J. (1980). Effects of loaf volume, moisture content and protein quality on the softness and staling rate of bread. Cereal Chem., 57 (2): 138-140.

Muchiri, D. R.; Mahungu, S. M. and Gituanja, S. N. (2012). Studies on Mango (Mangifera indica L.) kernel fat of some Kenyan varieties in Meru. Journal of the American Oil Chemist's Society, 89: 1567-1575.

Prosky, L.; Georg, N.A.; Schweizer, T.F.; Devries, J.W. and Furda, I. (1988). Determination of insoluble, soluble, and total dietary fiber in foods and food products: inter laboratory study. J. Assoc. Off. Anal. Chem., 71 (5): 1017-1023.

Ravani, A. and Joshi, D.C. (2013). Mango and it's by product utilization-a review. Trends in post-harvest technology, 1 (1): 55-67.

SAS (2010). Statistical Analysis System. User's Guide: Statistics, SAS Institute Inc, Gary, Nc., USA.
Sharoba, A.M.; Farrag, M.A. and Abd El-Salam, A.M (2013). Utilization of some fruits and vegetables waste as a source of dietary fiber and its effect on the cake making and its quality attributes. Journal of Agroalimentary Processes and Technologies, 19(4): 429-444.

Solís-Fuentes, J. A. and Durán-de-Bazúa, M. C. (2011). Mango (Mangifera indica L.) seed and its fats. In V. Preedy, R. R. Watson, \& V. B. Patel (Eds.), Nuts and Seeds in health and disease prevention (pp. 741-748). San Diego: Academic Press. Chapter 88.

Stanley, P. C. and Linda, S. Y. (2006). Baked products: Science, technology and practice. Blackwell Publishing Ltd. 36-37.

Stauffer, C.E. (2000). Emulsifiers as antistaling agents. Cereal Foods World 45: 106-110.

Sudhakar, D.V. and Maini, S.B. (2000). Isolation and characterization of mango peel pectins. Journal of Food Processing and Preservation, 24: 209-227.

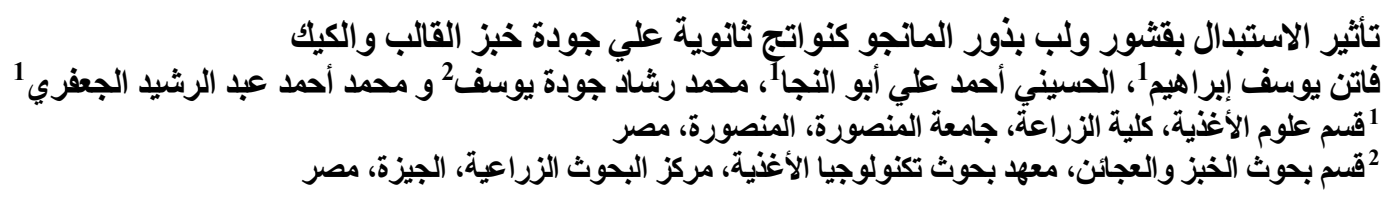

تعثبر فتور وبذور المانجو من اهم المنتجات الثانوية الناتجه عن صناعة عصير المانجو. وهي غنية بالمركبات الطبيعية النشطة بيولوجيا

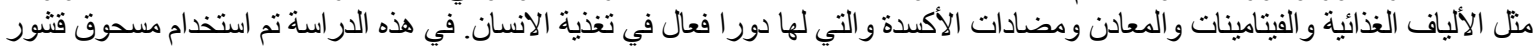

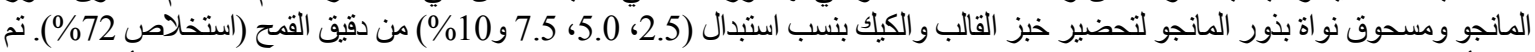

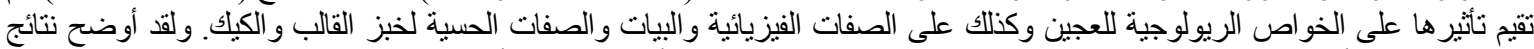

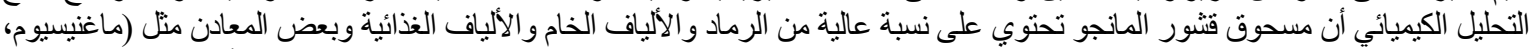

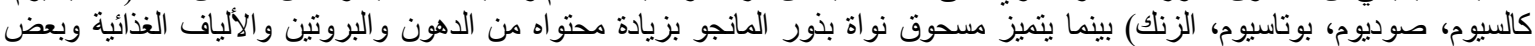

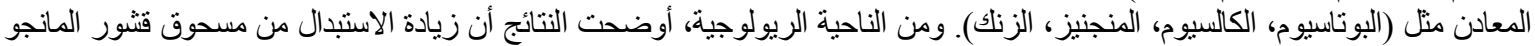

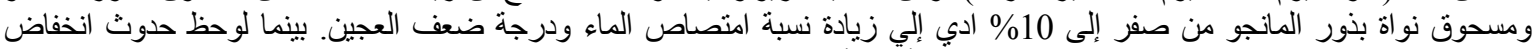

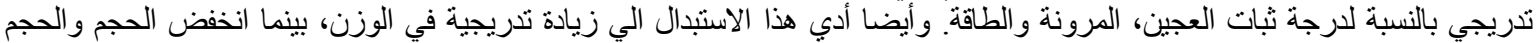

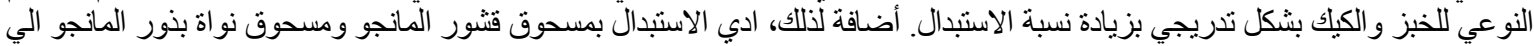

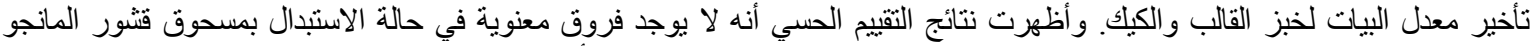

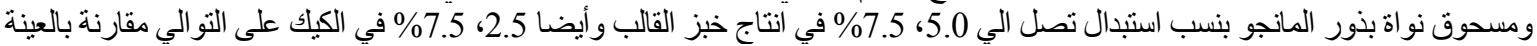

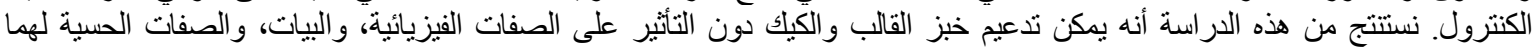
بمسحوق قشور المانجو (بنسبة 5.5\%) أو مسحوق نواة بذور المانجو بنسب تصل الي 5.0\% وذلك لاستفادة من المركبات الفعالة الموجودة بكلا الكلمات الدالة: خبز القالب ـ الكيك ـ قثتور المانجو ـ نواة بذور المانجو ـ الخصائص الريولوجية ـ جودة منتجات المخابز. 